\title{
RARE EARTH ELEMENT EXTRACTION FROM PRETREATED BASTNÄSITE IN SUPERCRITICAL CARBON DIOXIDE
}

\author{
*L.K. Sinclair ${ }^{\mathrm{a}}$, D.L. Baek ${ }^{\mathrm{b}}$, J. Thompson ${ }^{\mathrm{a}}$, J.W. Tester ${ }^{\mathrm{a}}$, R.V. Fox ${ }^{\mathrm{b}}$ \\ ${ }^{a}$ Cornell University \\ Energy Institute \\ Departments of Chemical and Biomolecular Engineering / Earth and Atmospheric Sciences \\ Snee Hall, Cornell University \\ Ithaca, New York, U.S.A. 14853 \\ (*Corresponding author: lks82@cornell.edu) \\ ${ }^{b}$ Idaho National Laboratory \\ 775 University Boulevard \\ Idaho Falls, Idaho U.S.A. 83415
}

\begin{abstract}
Rare earth elements are a critical component in many clean energy technologies. Extraction of individual rare earth elements from natural ores or recycled material is challenging due to the very similar chemical properties across the lanthanide series. Supercritical carbon dioxide has emerged in recent years as a possible extraction medium for rare earth elements, due to its tunability and selectivity as a solvent. In this study, rare earth elements were recovered from bastnäsite concentrate using supercritical carbon dioxide extraction with nitric acid/tributyl phosphate adducts. Two bastnäsite pretreatment methods were used to render the rare earth elements amenable to recovery: 1) dry roasting of the source material at $730^{\circ} \mathrm{C}$ for 3 hours, and 2) decomposition with $50 \%$ sodium hydroxide solution at $150^{\circ} \mathrm{C}$ for 4 hours. These pretreated powder samples were extracted in supercritical carbon dioxide at $34 \mathrm{MPa}$ and $65^{\circ} \mathrm{C}$, with kinetic samples obtained at 15-30 minute intervals. A range of tributyl phosphate/nitric acid adduct compositions (from $2 \mathrm{~mol} / \mathrm{L} \mathrm{H}^{+}$to $6 \mathrm{~mol} / \mathrm{L} \mathrm{H}^{+}$) were used in order to determine the effect of adduct composition on recovery rate. The results showed the fastest extraction with an adduct containing approximately $4 \mathrm{M} \mathrm{HNO}_{3}$. Adducts with higher acidity showed reduced extraction of cerium, praseodymium, and neodymium. This could be due to the formation of aqueous droplets which dissolve rare earth elements and create an equilibrium limitation, or due to competition between the rare earth nitrates and nitric acid for coordination with tributyl phosphate. Extraction with various adduct concentrations in supercritical $\mathrm{CO}_{2}$ showed the expected increase in reaction rate with increased adduct concentration. For the $4 \mathrm{~mol} / \mathrm{L} \mathrm{H}^{+}$adduct at $5.0 \mathrm{~mol} \%$ adduct concentration, roasted bastnäsite recoveries were $72 \%$ for $\mathrm{La}, 96 \%$ for $\mathrm{Ce}, 88 \%$ for Pr, and $90 \%$ for $\mathrm{Nd}$ after 120 minutes. For 4 $\mathrm{mol} / \mathrm{L} \mathrm{H}^{+}$adduct at $5.1 \mathrm{~mol} \%$ adduct concentration, $\mathrm{NaOH}$ digested bastnäsite recoveries were $93 \%$ for $\mathrm{La}, 100 \%$ for Ce, $99 \%$ for Pr, and $101 \%$ for Nd after 90 minutes. Though further research is needed, these results are a key step in demonstrating applicability of supercritical extraction to rare earth element ores.
\end{abstract}

\section{KEYWORDS}

Rare earth elements; lanthanides; bastnäsite; carbon dioxide; tributyl phosphate; supercritical fluid extraction

(C) 2016. This manuscript version is made available under the Elsevier user license

http://www.elsevier.com/open-access/userlicense/1.0/ 


\section{INTRODUCTION}

\subsection{Motivation}

Rare earth elements (REEs) consist of the 15 lanthanides, scandium, and yttrium. REEs are used in a wide array of applications including electronics, magnets, catalysts, glass, and solid-state lighting. Many of these applications are critical for strategic technologies in clean energy and defense [1]. Because of the United States' dependence on imported REEs for critical industries, the United States Department of Energy has sought technologies to diversify domestic supplies of REEs [2]. This need was exacerbated in 2015 with the cessation of operations at Mountain Pass, the United States' only domestic REE mine.

A key part of the Department of Energy's strategy is the development of improved methods for the recovery of individual REEs from ores and recycled streams with reduced costs and environmental impact. Conventional extraction and separation of REEs from ores involves beneficiation to obtain a concentrate, followed by various types of high-temperature processes to break down REE minerals into readily soluble compounds. Metals are then solubilized using acid leaching, followed by various combinations of precipitation and solvent extraction to isolate individual REE products. Ion exchange can also be used for small-volume production of higher purity products [3].

These conventional processing routes require numerous steps and hence face significant environmental and economic challenges, especially in separating various REEs from each other through solvent extraction. Given the chemical similarity among the elements in the lanthanide series, conventional solvent extraction systems achieve only slight separation of adjacent lanthanides. For example, one study reported separation factors for tributyl phosphate $/ \mathrm{HNO}_{3}$ as 1.01 to 2.26, and separation factors in di-(2-ethylhexyl)phosphoric acid/ $\mathrm{HCl}$ as 0.95 to 2.17 [4]. As a result, hundreds of mixer/settler stages are sometimes required in order to obtain high purity products [1]. Depending on the extractant employed, solvent extraction may also require high acid concentrations in the strip solution, which results in high acid consumption with associated costs and potential environmental impacts [1,5,6].

In this paper, we discuss the first phase in evaluating the efficacy of supercritical fluids for the extraction of REE from REE-bearing minerals. Subsequent research will assess the tenability of this method to recover individual REEs. If successful, the result will be a potentially more efficient method of REE extraction requiring further test work, scale-up, and economic analysis.

\subsection{Supercritical Fluid Extraction}

Supercritical fluid extraction (SFE) using carbon dioxide offers an alternative technology for the extraction of REEs. In order to dissolve a metal species in supercritical $\mathrm{CO}_{2}$, three conditions must be met: 1 . the metal ions must be rendered charge neutral through bonding or association with a negatively charged species, 2 . the metal must be coordinatively satisfied (again through bonding), and 3. the resulting metal-ligand complex must be nonpolar so it can dissolve in the nonpolar $\mathrm{CO}_{2}$ phase.

A wide array of chemistries have been used to satisfy these three requirements, including beta diketones and organophosphorous extractants [7]. The tributyl phosphate (TBP) and nitric acid system has received particular attention in recent years. In this system, nitrate anions bond with trivalent lanthanides to form a nitrate salt, and then TPB molecules substitute for coordinated water surrounding the salt to form a $\mathrm{CO}_{2}$-soluble complex (see Figure 1).

REEs can be extracted in supercritical $\mathrm{CO}_{2}$ as a TBP/nitrate complex in several different ways. Supercritical $\mathrm{CO}_{2}$ with TBP has been used to extract REEs (and actinides) from aqueous nitrate solutions [8-10] and from solid nitrate salts [11-13]. Another option is to premix TBP and $\mathrm{HNO}_{3}$ to form a liquid adduct, dissolve this adduct in supercritical $\mathrm{CO}_{2}$, and use this modified $\mathrm{CO}_{2}$ to extract REEs from acid-soluble mineral phases such as oxides [14-19]. In the latter configuration, the extraction mechanism involves three sequential steps in a single reaction vessel: reaction of REE minerals with nitric acid to form REE nitrates, complexation of the nitrate salt with $\mathrm{TBP}$, and dissolution of the metal complex in $\mathrm{CO}_{2}$. 

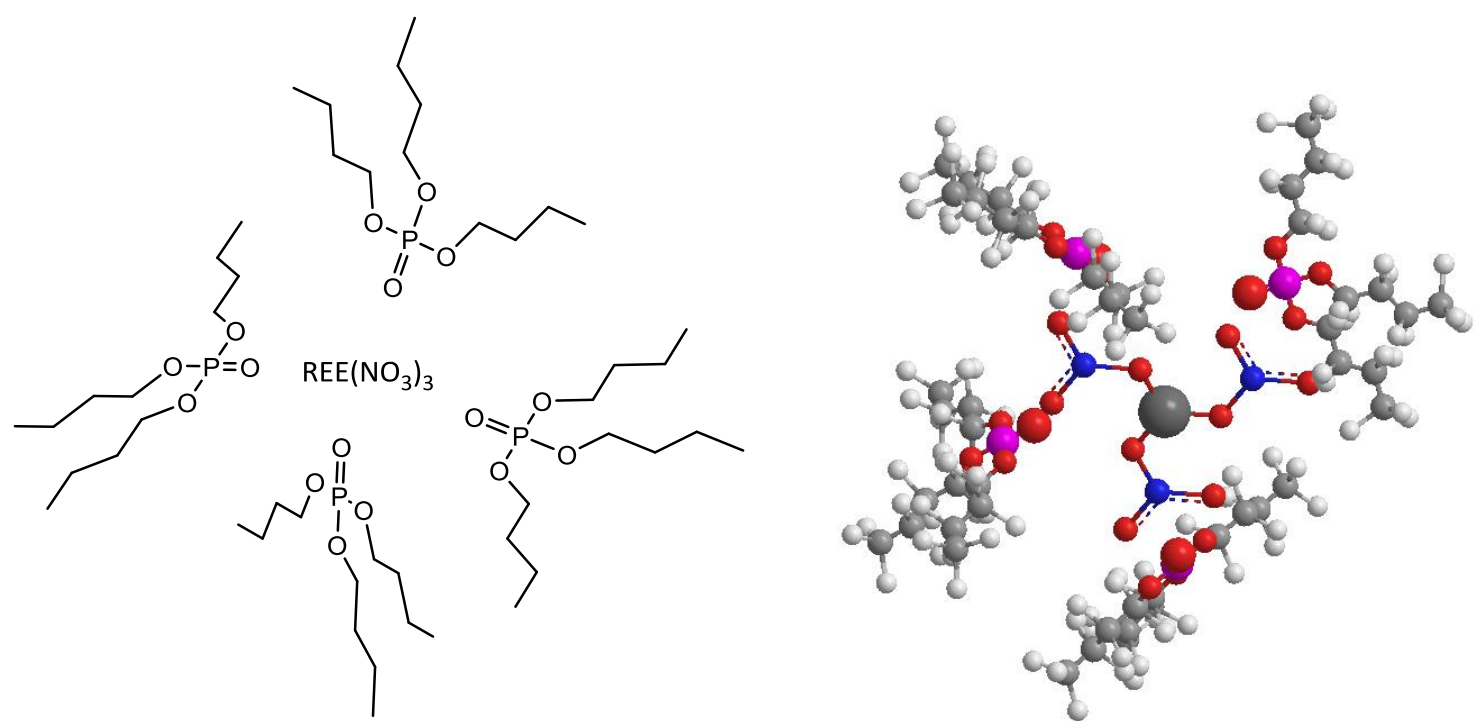

Figure 1 - Schematic of rare earth element nitrate complexed with four tributyl phosphate molecules (left). Ball and stick model (right). Small grey=carbon, red=oxygen, blue=nitrogen, magenta=phosphorus, white=hydrogen, large grey=REE.

Although extraction from oxides and nitrates has been demonstrated, application of SFE to ore samples has been limited [18]. If proven viable, SFE could potentially replace the leaching and solvent extraction steps in conventional processing. In this proposed process, ores would undergo conventional concentration and pretreatment steps to obtain an acid-soluble mineral, and then a supercritical phase containing a dissolved $\mathrm{TBP} / \mathrm{HNO} \mathrm{O}_{3}$ adduct would be used to extract REEs directly from the solid matrix. The REEs could then be precipitated via a reduction in pressure, and the $\mathrm{CO}_{2}$ can be recycled back to the extraction step. Depending on downstream processing stages, it may also be possible to recycle the TBP back to the extraction stage, thus reducing reagent costs. If various metals have differing relationships between pressure and solubility, sequential pressure reductions could be exploited as a separation mechanism. Such a process could present several advantages over conventional leaching/solvent extraction technology:

- Selective extraction of lanthanides over alkaline, alkaline earth, and transition metals

- Reduced residence time requirements for extraction due to the high diffusivity of supercritical carbon dioxide

- Potential reduction of the number of equilibrium stages required for separation

- Reduction in acid consumption by precipitating REEs from the supercritical phase via pressure reduction rather than acid stripping

- Elimination of flammability issues through replacement of organic solvents such as kerosene with nonflammable $\mathrm{CO}_{2}$

\subsection{Objective and Approach}

The goal of this work is to quantitatively evaluate the technical feasibility of using supercritical $\mathrm{CO}_{2}$ to extract REEs from bastnäsite as a first step in demonstrating the applicability of SFE to existing primary sources. Today REE recovery from bastnäsite, a cerium- and lanthanum-dominant REE fluorocarbonate mineral, accounts for approximately $70 \%$ of worldwide REE production [20]. In this study, pretreated bastnäsite concentrate was exposed to a supercritical $\mathrm{CO}_{2}$ phase containing $\mathrm{TBP} / \mathrm{HNO}_{3}$ adducts to selectively extract the REEs. Two pretreatment methods were evaluated in this study given their dominant use in conventional bastnäsite concentrate processing: roasting and $\mathrm{NaOH}$ digestion. In an earlier study, a third commonly applied industrial pretreatment involving roasting with sulfuric acid was eliminated due to poor recoveries [21]. A range of adduct compositions (TBP/ $\mathrm{HNO}_{3}$ ratio) and adduct concentrations in $\mathrm{CO}_{2}$ (mol\% adduct in supercritical phase) were evaluated to examine the effect on extraction kinetics. 


\section{MATERIALS AND METHODS}

This section includes a description of the materials employed in this study, a description of the bastnäsite pretreatment processes, characterization of the pretreated samples, and a description of the supercritical extraction setup and procedure.

\subsection{Reagents}

Dry molecular sieves were acquired from Delta Adsorbents (mSorb 3A $8 \times 12$ IMS, Delta Adsorbents, Roselle, IL) and dried in a vacuum oven overnight at $523 \mathrm{~K}\left(250{ }^{\circ} \mathrm{C}\right)$ prior to use. Tri-n-butyl phosphate (TBP, 97\%), trace metal grade concentrated nitric acid, and silanized glass wool were purchased from Sigma-Aldrich (St. Louis, MO). The TBP was dried to $<300 \mathrm{ppm}_{2} \mathrm{O}$ with the molecular sieves prior to use. Fuming nitric acid (ACS grade, $21.2 \mathrm{M},>90 \%$ w/w) was obtained from Macron Fine Chemicals (Center Valley, PA) and utilized as received. ACS grade sodium hydroxide pellets were purchased from Thermo Fisher Scientific (Hampton, NH). Granular, ultrapure lithium metaborate and lithium tetraborate were purchased from SPEX CertiPrep (Metuchen, NJ). A bone dry liquid carbon dioxide tank with a siphon was purchased from Airgas (Radnor, PA).

\subsection{Bastnäsite Concentrate}

Bastnäsite concentrate was obtained from the Mountain Pass mine in California, the United States' only recently active REE mine, which ceased operations in 2015. At Mountain Pass, bastnäsite ore grading approximately $7 \%$ rare earth oxides was fed to a froth flotation and weak acid leach process where it was concentrated to approximately $70 \%$ REO [3].

X Ray Diffraction (XRD) (Bruker D8 Discover, Bruker Corporation, Billerica, MA) was used to confirm the presence of the expected mineral phases in the bastnäsite concentrate sample as shown in Figure 2. The observed peaks correspond to the presence of bastnäsite, hydroxylbastnäsite, and possibly barite. This is consistent with the reported composition of Mountain Pass concentrate [3].

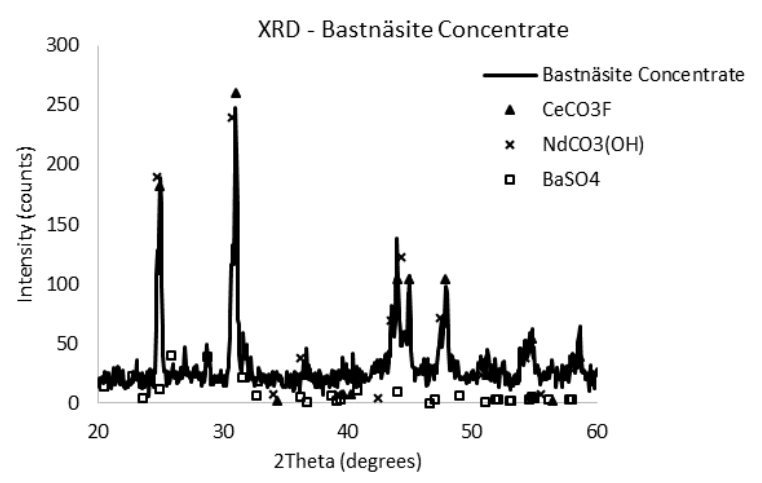

Figure 2 - XRD patterns of bastnäsite $\left(\mathrm{CeCO}_{3} \mathrm{~F}\right.$ : PDF\#00-011-0340. $\mathrm{NdCO}_{3}(\mathrm{OH}): \mathrm{PDF} 00-038-0400 . \mathrm{BaSO}_{4}$ : PDF\#00-005-0448 [22].

\subsection{Pretreatment Methods}

\subsubsection{Roasting}

\subsubsection{Chemistry}

Conventional bastnäsite concentrate processing often begins with roasting to break down the fluorocarbonate structure. The chosen temperature will depend on the type of processing to be conducted further downstream, and may also depend on the ratio of carbonate to fluoride content in the ore. Roasting has three purposes: to further concentrate the REEs by driving off $\mathrm{CO}_{2}$, to increase the acid solubility of rare earths, and sometimes to oxidize cerium to its tetravalent state [1,23].

The chemistry of the roasting process depends on the roasting temperature chosen and the residence time. If the concentrate is roasted to $400-500^{\circ} \mathrm{C}$, the bastnäsite mineral is oxidized to form oxyfluorides (Reaction 1), and $\mathrm{CO}_{2}$ gas is driven off [3,24]. At temperatures between $500^{\circ} \mathrm{C}$ and $700^{\circ} \mathrm{C}$, the oxyfluorides are gradually further transformed into acid-soluble oxides and insoluble trifluorides. HF gas is released in the process (Reaction 2) $[24,25]$. Between 700 and $1000^{\circ} \mathrm{C}$, cerium can also oxidize to form insoluble cerianite (Reaction 3), allowing for the 
separation of cerium from other REEs in downstream leaching steps [24]. The roasted bastnäsite is now much more easily dissolved in mineral acids such as nitric acid (Reaction 4).

\begin{tabular}{|c|c|c|c|}
\hline \multirow{2}{*}{$\mathrm{REEFCO}_{3(\mathrm{~s})}$} & $400-500^{\circ} \mathrm{C}$ & \multirow{2}{*}{$\mathrm{REEOF}_{(\mathrm{s})}+\mathrm{CO}_{2(\mathrm{~g})}$} & \multirow[b]{2}{*}{ (Reaction 1) } \\
\hline & $\Delta$ & & \\
\hline \multirow[b]{2}{*}{$5 \operatorname{REEOF}_{(\mathrm{s})}+\mathrm{H}_{2} \mathrm{O}_{(\mathrm{g})}$} & $500-700^{\circ} \mathrm{C}$ & \multirow[b]{2}{*}{$2 \mathrm{REE}_{2} \mathrm{O}_{3(\mathrm{~s})}+\mathrm{REEF}_{3(\mathrm{~s})}+2 \mathrm{HF}_{(\mathrm{g})}$} & \multirow[b]{2}{*}{ (Reaction 2) } \\
\hline & $\Delta$ & & \\
\hline \multirow[b]{2}{*}{$\mathrm{Ce}_{2} \mathrm{O}_{3(\mathrm{~s})}+0.5 \mathrm{O}_{2(\mathrm{~g})}$} & $700-1000^{\circ} \mathrm{C}$ & \multirow[b]{2}{*}{$2 \mathrm{CeO}_{2(\mathrm{~s})}$} & \multirow[b]{2}{*}{ (Reaction 3) } \\
\hline & $\Delta$ & & \\
\hline $0.5 \mathrm{REE}_{2} \mathrm{O}_{3(\mathrm{~s})}+3 \mathrm{HNO}_{3(\mathrm{aq})}$ & $\rightarrow$ & $\operatorname{REE}\left(\mathrm{NO}_{3}\right)_{3(\mathrm{aq})}+1.5 \mathrm{H}_{2} \mathrm{O}_{(\mathrm{aq})}$ & (Reaction 4) \\
\hline
\end{tabular}

\subsubsection{Procedure}

In an effort to make a comparison with current methods, conditions were chosen that were similar to conventional bastnäsite roasting temperatures. For this study, bastnäsite was dried overnight under vacuum at $100^{\circ} \mathrm{C}$ and $15 \mathrm{~g}$ was then weighed into a porcelain crucible. The powder was baked for 3 hours at $730^{\circ} \mathrm{C}$ at atmospheric pressure.

\subsubsection{Characterization}

The elemental composition of the roasted bastnäsite concentrate was obtained via duplicate $\mathrm{LiBO}_{2} / \mathrm{Li}_{2} \mathrm{~B}_{4} \mathrm{O}_{7}$ fusion and Inductively Coupled Plasma Optical Emission Spectrometry (ICP-OES) (SpectroBlue Side-On Plasma, Spectro Analytical Instruments, Kleve, Germany) (see Table 1). The composition of the original bastnäsite concentrate was calculated based on the roasted bastnäsite assay and the measured mass loss during roasting. XRD was used to identify mineral phases (see Figure 3). The results are in agreement with a cerium and lanthanum oxide mixture and/or an oxyfluoride mixture: $\mathrm{Ce}_{2} \mathrm{O}_{3}, \mathrm{LaF}_{3}, \mathrm{CeF}_{3}$, and $\mathrm{Ce}\left(\mathrm{CO}_{3}\right) \mathrm{F}$ were not identified, suggesting full conversion of the bastnäsite to oxides and/or oxyfluorides with little formation of trifluorides. This could be indicative of low fluoride levels in the source material.

Sonic sifting (model L3P, ATM Corporation, West Allis, WI) was used to measure the particle size distribution (see Figure 4). The results indicated a P80 of approximately 45 microns. Sieves used are considered accurate to $+/-2$ microns [26]. Size distributions in the $<10$ micron range could not be measured.

Table 1: Elemental Composition of Raw and Pretreated Bastnäsite Samples

\begin{tabular}{|l|c|c|c|c|c|c|c|c|c|c|c|}
\hline Material & $\mathrm{La}$ & $\mathrm{Ce}$ & $\mathrm{Pr}$ & $\mathrm{Nd}$ & $\mathrm{Sm}$ & $\mathrm{Eu}$ & $\mathrm{Gd}$ & $\mathrm{Tb}$ & $\mathrm{Ba}$ & $\mathrm{Ca}$ & $\mathrm{Sr}$ \\
\hline Raw Bastnäsite & $20.7 \%$ & $28.0 \%$ & $2.5 \%$ & $6.6 \%$ & $0.5 \%$ & $<0.2 \%$ & $0.2 \%$ & $0.1 \%$ & $3.5 \%$ & $0.7 \%$ & $3.5 \%$ \\
\hline Roasted Bastnäsite & $25.1 \%$ & $34.1 \%$ & $3.0 \%$ & $8.0 \%$ & $0.6 \%$ & $<0.2 \%$ & $0.2 \%$ & $0.1 \%$ & $4.3 \%$ & $0.9 \%$ & $4.2 \%$ \\
\hline NaOH Digested Bastnäsite & $25.2 \%$ & $33.1 \%$ & $3.0 \%$ & $7.7 \%$ & $0.5 \%$ & $<0.2 \%$ & $0.2 \%$ & $0.1 \%$ & $3.6 \%$ & $1.0 \%$ & $<1.7 \%$ \\
\hline $\begin{array}{l}\text { Reporting Limit (lowest } \\
\text { calibration standard) }\end{array}$ & $4.3 \%$ & $1.0 \%$ & $0.2 \%$ & $0.2 \%$ & $0.1 \%$ & $0.2 \%$ & $0.2 \%$ & $\begin{array}{c}0.03 \\
\%\end{array}$ & $0.8 \%$ & $0.3 \%$ & $1.7 \%$ \\
\hline
\end{tabular}




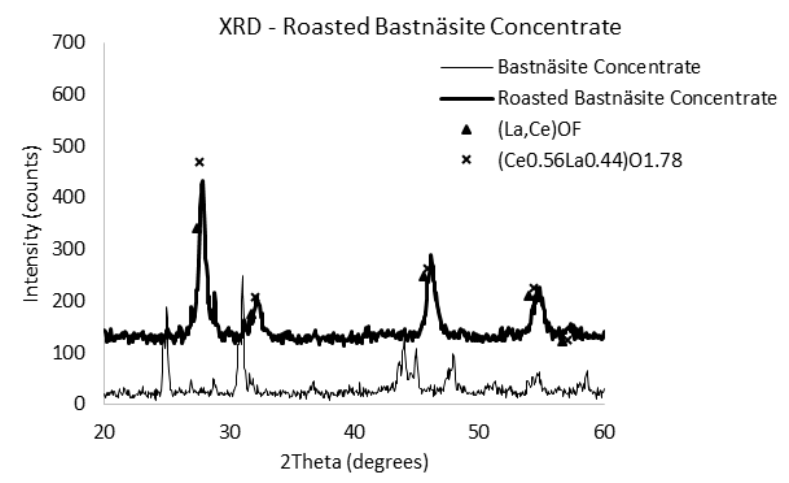

Figure 3 - XRD pattern for roasted bastnäsite concentrate ((La,Ce)OF: PDF\#00-057-0608. $\left(\mathrm{Ce}_{0.56} \mathrm{La}_{0.44}\right) \mathrm{O}_{1.78}$ : PDF\#01-071-6545) [22]

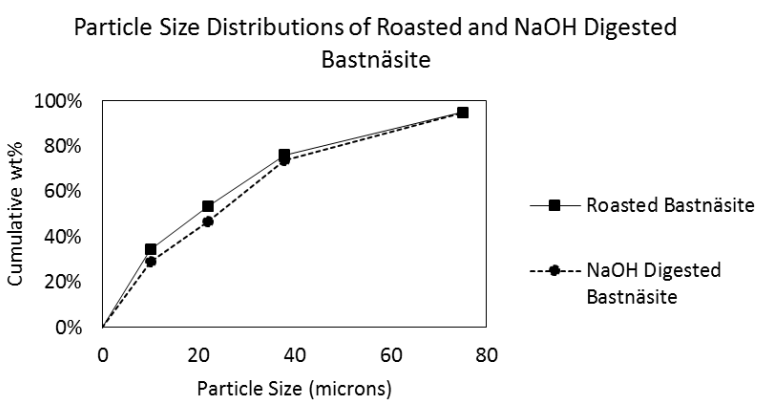

Figure 4 - Measured particle size distribution of roasted and $\mathrm{NaOH}$ digested bastnäsite

\subsubsection{Sodium Hydroxide Digestion}

\subsubsection{Chemistry}

Sodium hydroxide digestion can convert bastnäsite into acid-soluble rare earth hydroxides. This involves combining the minerals with a concentrated $\mathrm{NaOH}$ solution at elevated temperature $\left(>140^{\circ} \mathrm{C}\right)$ for $1-5$ hours to convert the fluorocarbonates to solid hydroxides as illustrated in Reaction 5. The solid hydroxides are then easily dissolved in mineral acids such as nitric acid with the overall stoichiometry given by Reaction 6. Sodium hydroxide digestion is used for commercial bastnäsite processing, often in combination with roasting [4,27].

$$
\begin{array}{llll}
\mathrm{REEFCO}_{3(\mathrm{~s})}+3 \mathrm{NaOH}_{(\mathrm{aq})} & \rightarrow & \mathrm{REE}(\mathrm{OH})_{3(\mathrm{~s})}+\mathrm{NaF}_{(\mathrm{aq})}+\mathrm{Na}_{2} \mathrm{CO}_{3(\mathrm{aq})} & \text { (Reaction 5) } \\
\mathrm{REE}(\mathrm{OH})_{3(\mathrm{~s})}+3 \mathrm{HNO}_{3(\mathrm{aq})} & \rightarrow & \mathrm{REE}\left(\mathrm{NO}_{3}\right)_{3(\mathrm{aq})}+3 \mathrm{H}_{2} \mathrm{O}_{(\mathrm{aq})} & \text { (Reaction 6) }
\end{array}
$$

\subsubsection{Procedure}

The bastnäsite sample was dried overnight under vacuum at $100^{\circ} \mathrm{C}$ and $15 \mathrm{~g}$ of dried powder was weighed into a $280 \mathrm{~mL}$ Parr reaction vessel (Parr Instrument Company, Moline, IL). $100 \mathrm{~mL}$ of $50 \mathrm{wt} \% \mathrm{NaOH}$ solution was added. The powder and caustic solution were mixed with a stir bar until a homogenized slurry was achieved. The stirred reactor was then sealed and heated to $150^{\circ} \mathrm{C}$ using heating tape connected to a controller. Heating the reactor took approximately 75 minutes. The reactor was then held at $150^{\circ} \mathrm{C}$ for four hours, then allowed to cool below $80^{\circ} \mathrm{C}$ and opened. Cooling took approximately one hour.

After the reactor was opened, the slurry was transferred to a polypropylene centrifuge bottle and agitated in an ice bath for 10 minutes. The slurry was washed 3 times with $100 \mathrm{~mL}$ of ultrapure water (18.2 M $\Omega$-cm) to remove residual $\mathrm{NaOH}$. After each wash, the slurry was centrifuged and supernatant was removed. Finally, the slurry was filtered on Whatman grade 40 ashless filter paper ( 8 microns), and dried overnight under vacuum at $100^{\circ} \mathrm{C}$.

\subsubsection{Characterization}

Duplicate $\mathrm{LiBO}_{2} / \mathrm{Li}_{2} \mathrm{~B}_{4} \mathrm{O}_{7}$ fusion and ICP-OES was used to establish the composition of the $\mathrm{NaOH}$ digested sample (see Table 1). Assays indicated negligible losses of the REEs, with the exception of Eu which could not be 
measured reliably as the concentration was below the reporting limit. XRD showed the presence of $\mathrm{Ba}_{4} \mathrm{La}_{2} \mathrm{O}_{7}$ and $\mathrm{Nd}(\mathrm{OH})_{3}$, with possible presence of $\mathrm{Ce}(\mathrm{OH})_{3}$ (see Figure 5). $\mathrm{La}(\mathrm{OH})_{3}$ could not be positively identified.

Sonic sifting was used to obtain a rough particle size distribution (see Figure 4). The results indicated a P80 of approximately 45 microns, nearly identical to the roasted sample.

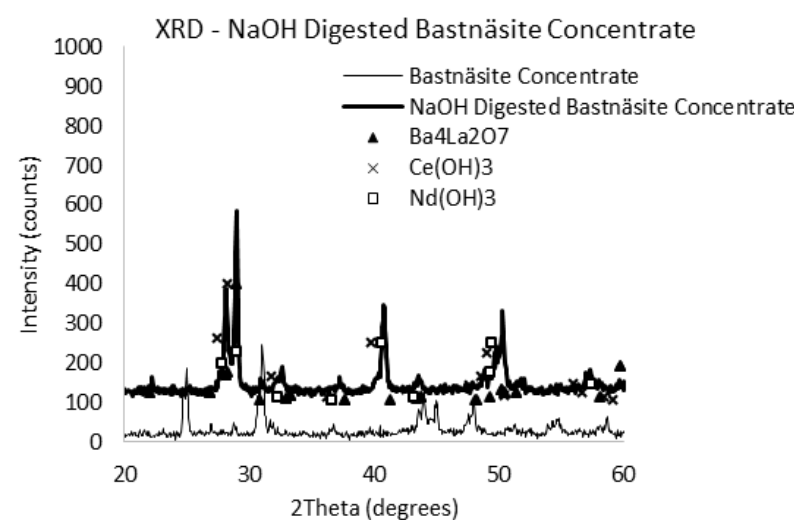

Figure 5 - XRD pattern of $\mathrm{NaOH}$ digested bastnäsite concentrate $\left(\mathrm{Ba}_{4} \mathrm{La}_{2} \mathrm{O}_{7}\right.$ : PDF\# 00-052-1324. $\mathrm{Ce}(\mathrm{OH})_{3}$ : PDF\#00-055-0556. $\mathrm{Nd}(\mathrm{OH})_{3}$ : PDF\#00-006-0601 [22]

\subsection{Atmospheric Leaching}

Treated and untreated bastnäsite samples were leached with concentrated nitric acid to confirm the formation of soluble REE mineral structures and to provide a baseline recovery for comparison with conventional processing. For these experiments, $1 \mathrm{~g}$ of material was leached in $30 \mathrm{~mL}$ nitric acid for 3 hours. Solids were washed twice and vacuum filtered. Leachate and wash water were assayed with ICP-OES. As shown in Table 2, high REE recoveries (93-102\%) were measured for both of the pretreated samples. The high cerium recovery in the roasted sample suggests that the cerium remained in the trivalent state.

Table 2 - Nitric acid leaching recoveries of REEs in raw and pretreated bastnäsite concentrate samples

\begin{tabular}{|l|c|c|c|c|c|c|c|}
\hline Material & $\mathrm{La}$ & $\mathrm{Ce}$ & $\mathrm{Pr}$ & $\mathrm{Nd}$ & $\mathrm{Ba}$ & $\mathrm{Ca}$ & $\mathrm{Sr}$ \\
\hline Raw Bastnäsite & $17 \%$ & $18 \%$ & $19 \%$ & $18 \%$ & $8 \%$ & $84 \%$ & $40 \%$ \\
\hline Roasted Bastnäsite & $94 \%$ & $95 \%$ & $95 \%$ & $93 \%$ & $7 \%$ & $81 \%$ & $36 \%$ \\
\hline NaOH Digested Bastnäsite & $94 \%$ & $95 \%$ & $102 \%$ & $96 \%$ & $92 \%$ & $97 \%$ & $83 \%$ \\
\hline $\begin{array}{l}\text { Reporting Limit (lowest } \\
\text { calibration standard) }\end{array}$ & $0.04 \%$ & $0.1 \%$ & $1.2 \%$ & $0.1 \%$ & $0.2 \%$ & $0.8 \%$ & $0.02 \%$ \\
\hline
\end{tabular}

\subsection{Adduct Preparation}

The TBP/ $/ \mathrm{HNO}_{3}$ adducts were prepared by shaking dry TBP $\left(<300 \mathrm{ppm} \mathrm{H}_{2} \mathrm{O}\right)$ with fuming $\mathrm{HNO}_{3}$ at various volume ratios for five minutes, following the procedure from previous studies [16,28]. All of the adduct compositions used in this study resulted in a single phase. The stoichiometry of the formulated complexes can be represented as $\mathrm{TBP}\left(\mathrm{HNO}_{3}\right)_{\mathrm{x}}\left(\mathrm{H}_{2} \mathrm{O}\right)_{y}$. Karl Fisher titration (Metrohm $831 \mathrm{KF}$ Coulometer, Metrohm, Riverview, FL) and $\mathrm{NaOH}$ titration were used to establish the stoichiometry (acid and water content) of each adduct. Results are given in Table 3.

Table 3 - Stoichiometries in the form of TBP $\left(\mathrm{HNO}_{3}\right)_{\mathrm{x}}\left(\mathrm{H}_{2} \mathrm{O}\right)_{\mathrm{y}}$ for different adduct compositions

\begin{tabular}{|l|c|c|c|c|c|}
\hline Mixed $\mathrm{HNO}_{3}$ :TBP Volume Ratio & 0.1 & 0.18 & 0.25 & 0.33 & 0.43 \\
\hline Adduct $\mathrm{H}^{+}$Concentration, mol/L & 2 & 3 & 4 & 5 & 6 \\
\hline $\mathrm{x}$ & 0.63 & 1.00 & 1.38 & 1.85 & 2.44 \\
\hline $\mathrm{y}$ & 0.20 & 0.36 & 0.46 & 0.64 & 0.86 \\
\hline Density, $\mathrm{g} / \mathrm{mL}$ & 0.99 & 1.03 & 1.06 & 1.07 & 1.09 \\
\hline
\end{tabular}

Though in-line spectroscopic analysis of the metal complexes was not possible in this study, previous spectroscopic studies of $\mathrm{Pr}$ and $\mathrm{Nd}$ have demonstrated that four TBP molecules will coordinate with each 
$\mathrm{REE}\left(\mathrm{NO}_{3}\right)_{3}$ group during supercritical extraction when an aqueous phase is absent [11]. Using the values of $\mathrm{x}$ and $\mathrm{y}$ as determined above, the extraction reactions for the two REE materials can be balanced (see Reactions 7 and 8 ). It is clear from these reactions that excess water is present during extraction. For all adduct compositions $>2 \mathrm{~mol} / \mathrm{L} \mathrm{H}^{+}$, excess nitric acid is present as well.

$$
\begin{aligned}
& \mathrm{REE}(\mathrm{OH})_{3(\mathrm{~s})}+4 \mathrm{TBP}\left(\mathrm{HNO}_{3}\right)_{\mathrm{x}}\left(\mathrm{H}_{2} \mathrm{O}\right)_{\mathrm{y}(\mathrm{Sc})} \rightarrow(\mathrm{TBP})_{4} \mathrm{REE}\left(\mathrm{NO}_{3}\right)_{3(\mathrm{Sc})}+(4 \mathrm{x}-3) \mathrm{HNO}_{3(\mathrm{aq})}+(4 \mathrm{y}+3) \mathrm{H}_{2} \mathrm{O}_{(\mathrm{aq})} \\
& 0.5 \mathrm{REE}_{2} \mathrm{O}_{3(\mathrm{~s})}+4 \mathrm{TBP}\left(\mathrm{HNO}_{3}\right)_{\mathrm{x}}\left(\mathrm{H}_{2} \mathrm{O}\right)_{\mathrm{y}(\mathrm{Sc})} \rightarrow(\mathrm{TBP})_{4} \mathrm{REE}\left(\mathrm{NO}_{3}\right)_{3(\mathrm{Sc})}+(4 \mathrm{x}-3) \mathrm{HNO}_{3(\mathrm{aq})}+(4 \mathrm{y}+1.5) \mathrm{H}_{2} \mathrm{O}_{(\mathrm{aq})}
\end{aligned}
$$

(Reaction 7)

(Reaction 8)

A note of caution should be given with regard to mixing, handling, use, and storage of TBP and nitric acid mixtures. Mixtures comprised of concentrated (70\%) nitric acid and TBP have previously been characterized and widely reported in literature without mishap [14-19]. Care should be taken not to formulate mixtures of TBP and fuming nitric acid which would result in a mixture having greater than approximately $10 \mathrm{M} \mathrm{H}^{+}$in the organic phase because such mixtures have been found to be unstable and can undergo rapid exothermic decomposition (hydrolysis). Careful titration of acid reagents prior to use, and knowledge of the acid concentration, is important for safe practice. Mixtures of nitric with TBP should be made in a small test quantities (less than $10 \mathrm{~mL}$ ) first prior to creation of larger volume mixtures. Care should be exercised after $\mathrm{TBP}-\mathrm{HNO}_{3}$ mixtures are made to ensure they are stable and not emitting $\mathrm{NO}_{\mathrm{x}}$ vapors which could build-up and over-pressurize a storage container or centrifuge tube. Fresh solutions should be made and used, and not stored for periods greater than 72 hours. Solutions should be stored in chemically compatible containers and either kept in the hood for immediate use, or stored in an approved acid cabinet until used. If TBP $-\mathrm{HNO}_{3}$ mixtures $>6 \mathrm{M} \mathrm{H}^{+}$in the organic phase cannot be used in the same day, then they should be neutralized and discarded. Extracts arising from a supercritical fluid extraction process that contain metal, acid, and TBP should be handled in the manner described above. TBP $-\mathrm{HNO}_{3}$ mixtures should not be mixed with other organic reagents such as short-chain alcohols, aldehydes, ketones, and other common organic solvents (or waste solutions) which are incompatible with nitric acid. TBP that has come into contact with nitric acid should be neutralized first prior to being discarded.

\subsection{Experimental Supercritical Extraction System}

The SFE system is shown in Figure 6. All tubing and valves were purchased from High Pressure Equipment Company (Erie, PA). The system consisted of a $\mathrm{CO}_{2}$ pump (Teledyne Isco model 260D, Teledyne ISCO, Lincoln, NE) equipped with a cooling jacket used to cool the $\mathrm{CO}_{2}$ to $10^{\circ} \mathrm{C}$, an $\mathrm{HPLC}$ pump feeding the adduct (Dionex IP25, Dionex, Sunnyvale, CA), an equilibrium cell (custom machined at Idaho National Laboratory, approximately $45 \mathrm{~mL}$, equipped with a magnetic stir bar), and a reaction column which consisted of a short section of $9.5 \mathrm{~mm}$ O.D. steel tubing. This column contained the sample and silanized glass wool packing material, effectively forming a packed bed reactor. Material was held in place during extraction with $2 \mu \mathrm{m}$ filter frits $(9.5 \mathrm{~mm}$ diameter, $3.2 \mathrm{~mm}$ thickness, Applied Porous Technologies, Tariffville, CT) on each end of the column. Based on the density of silica and bastnäsite, it was estimated that the porosity of the reaction column was $92 \%$. The residence time of the reaction column was estimated at 20 seconds. The outlet tube was submerged in $20 \mathrm{~mL}^{\text {of }} 0.1 \mathrm{M} \mathrm{HNO}_{3}$ trap solution in a graduated cylinder, such that the depressurized $\mathrm{CO}_{2}$ bubbled through the solution.

The extraction pressure was set at $34 \mathrm{MPa}$ to dissolve the full range of adduct compositions by a comfortable margin [16] and a reaction column temperature of $65^{\circ} \mathrm{C}$ because extractions near this temperature had achieved high recoveries in previous studies $[14,15]$.

At the start of each run, $100 \mathrm{mg}$ of sample and $200 \mathrm{mg}$ of silanized glass wool packing material were loaded into the reaction column. The system was pressurized to $34 \mathrm{MPa}$. The equilibrium cell was held at $75^{\circ} \mathrm{C}$ and the reaction column was held at $65^{\circ} \mathrm{C}$. The reaction column inlet and outlet valves were then both closed, isolating the reaction column from the rest of the system. $\mathrm{CO}_{2}$ was fed continuously through the system via the bypass line. The micrometering valve position was manually adjusted to control the $\mathrm{CO}_{2}$ flow rate at approximately $3 \mathrm{~mL} / \mathrm{min}$. Adduct flow was then initiated, and both the $\mathrm{CO}_{2}$ and adduct were continuously fed through the bypass line for 40 minutes (approximately 3 times the residence time of the system) to obtain a steady state adduct concentration. At the start of the extraction, the bypass line was closed and the reaction column inlet and outlet lines were opened to direct flow through the reaction column. This type of extraction system is often referred to as "flow mode" or "dynamic mode", since the $\mathrm{CO}_{2}$ and adduct flow continuously through the reactor. Kinetic samples were taken at various time intervals by switching out different graduated cylinders at specified time points; this was facilitated by the three way valve at the outlet. After extraction was finished, $\mathrm{CO}_{2}$ was fed for another 30 minutes to flush out remaining adduct. 
As shown in previous work, the stoichiometries of metal containing complexes are altered when the complex is transferred from $\mathrm{CO}_{2}$ to a water-rich trap solution [29]. The resulting trap solutions separated over the course of each run into an aqueous phase and a TBP-rich organic phase. The organic phase from each run was triple stripped with $0.1 \mathrm{M} \mathrm{HNO}_{3}$ to remove all of the metal, and then this strip solution was combined with the aqueous phase. This was then analyzed via ICP-OES in order to calculate recovery. Several selected samples were stripped a fourth time in order to demonstrate that three strips are sufficient to recover all metal content.

The main sources of error are variations in $\mathrm{CO}_{2}$ flow rate, variations in the acidity of the fuming nitric acid, and variations in the ore and silica packing in the reaction column. To evaluate reproducibility, several runs were performed in duplicate or triplicate. Standard deviations for final recovery ranged from $1 \%$ to $6 \%$.

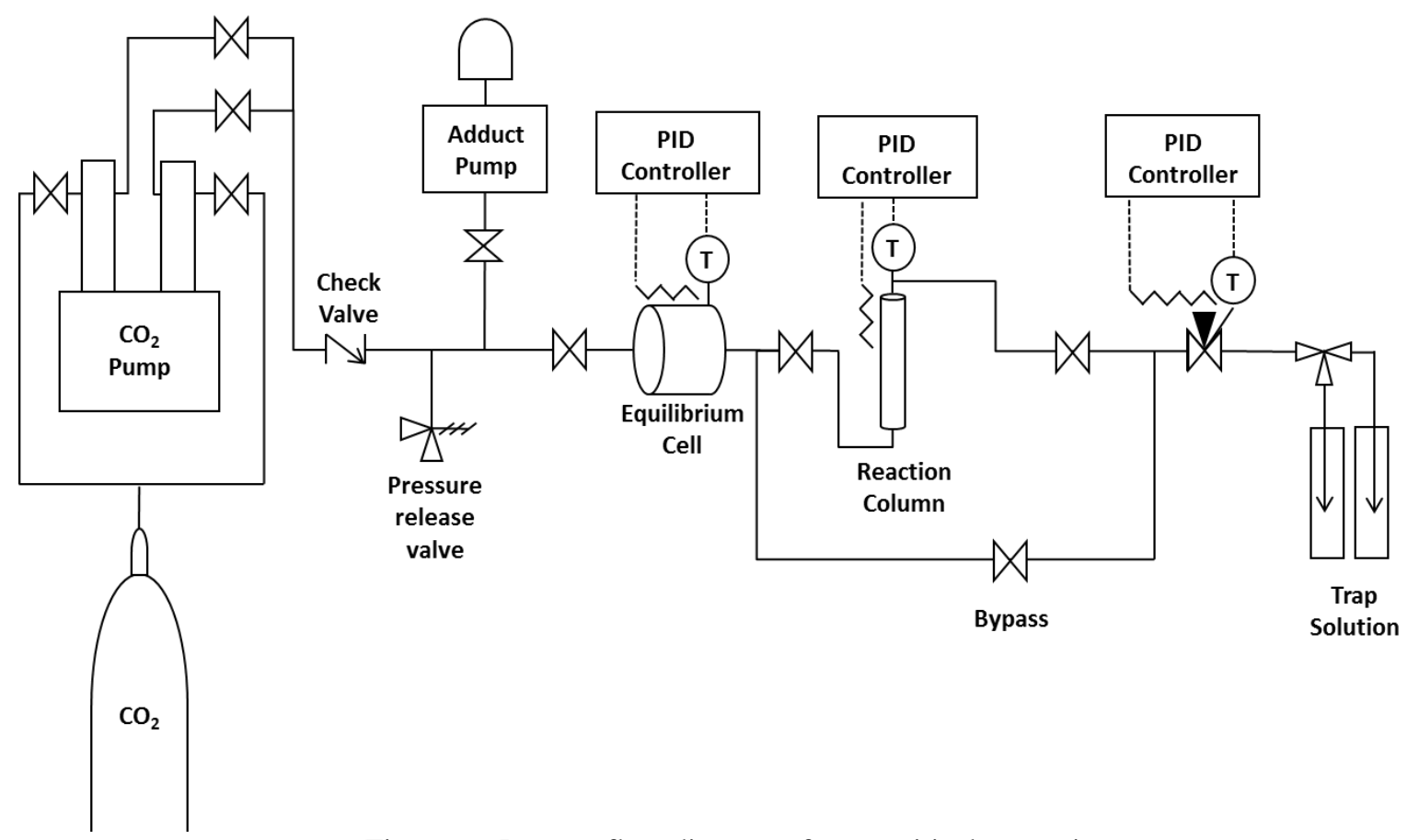

Figure 6 - Process flow diagram of supercritical extraction setup

\section{RESULTS AND DISCUSSION}

\subsection{Effect of Adduct Composition}

The results from the supercritical extraction runs are tabulated in Table 4. All recoveries are cumulative (include both losses incurred during pretreatment and losses incurred during supercritical extraction). An extraction was performed on an untreated bastnäsite sample in order to provide a comparison; REE recoveries were all $<10 \%$. The pretreated bastnäsite samples were then treated with a range of adduct compositions (all with $5.2+-0.8 \mathrm{~mol} \%$ adduct in the $\mathrm{CO}_{2}$ phase) in order to establish the optimum adduct composition for extraction. The recoveries for cerium are shown in Figure 7; data for $\mathrm{La}, \mathrm{Pr}$, and $\mathrm{Nd}$ can be found in Table 4. It is clear that both low acidity and high acidity adducts result in poor $\mathrm{Ce}, \mathrm{Pr}$, and $\mathrm{Nd}$ extraction, with the highest extraction rate achieved with the medium acidity adducts (approximately $3-5 \mathrm{~mol} / \mathrm{L} \mathrm{H}^{+}$). La recovery did not seem to fit this pattern - lower acidity adducts showed consistently better extraction. Potential explanations for this behavior are outlined in the Discussion section. 

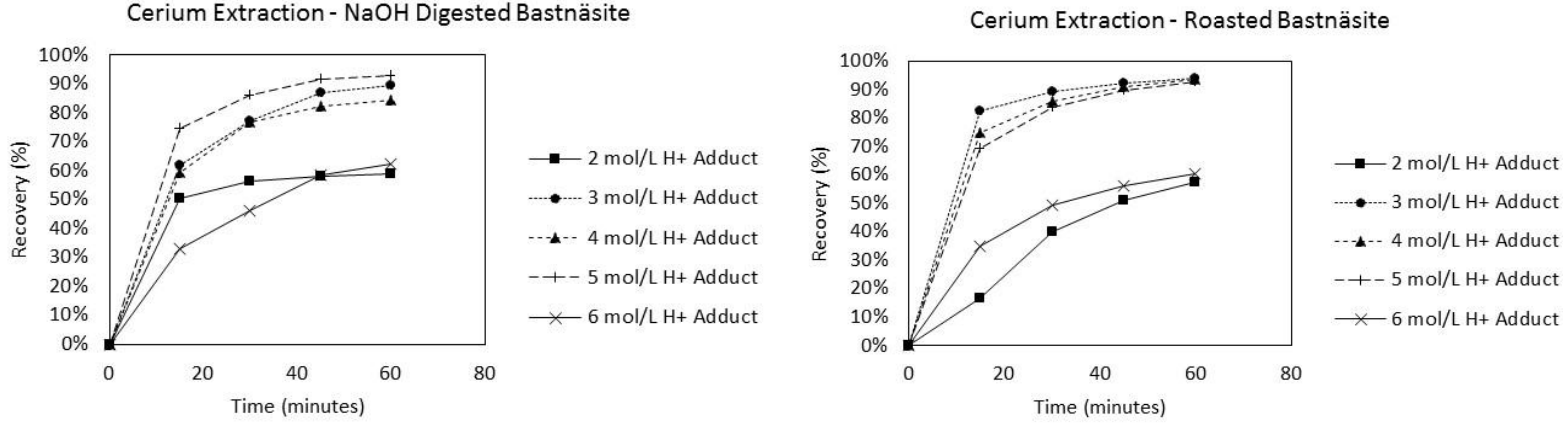

Figure 7 - Cerium recovery curves with various adduct compositions for roasted bastnäsite (left) and $\mathrm{NaOH}$ digested bastnäsite (right). Conditions: $34 \mathrm{MPa}, 65^{\circ} \mathrm{C}, 5.2+-0.8 \mathrm{~mol} \%$ adduct in $\mathrm{CO}_{2}$.

\subsection{Effect of Adduct Concentration in $\mathrm{CO}_{2}$}

After the $4 \mathrm{~mol} / \mathrm{L} \mathrm{H}^{+}$adduct was selected to be carried forward to the next phase of study, a range of adduct concentrations in the $\mathrm{CO}_{2}$ phase were tested in order to observe the effect on recovery. The extraction time was extended to 120 minutes for the roasted material and 90 minutes for the $\mathrm{NaOH}$ digested material in order to better resolve the recovery curve. The recovery curves for cerium are shown in Figure 8; data for La, $\mathrm{Pr}$, and $\mathrm{Nd}$ can be found in Table 4. As expected, higher adduct concentrations in $\mathrm{CO}_{2}$ resulted in faster recovery. For the $4 \mathrm{~mol} / \mathrm{L} \mathrm{H}^{+}$ adduct at $5.0 \mathrm{~mol} \%$ adduct concentration, roasted bastnäsite recoveries were $72 \%$ for $\mathrm{La}, 96 \%$ for $\mathrm{Ce}, 88 \%$ for $\mathrm{Pr}$, and $90 \%$ for $\mathrm{Nd}$ after 120 minutes. For $4 \mathrm{~mol} / \mathrm{L} \mathrm{H}^{+}$adduct at $5.1 \mathrm{~mol} \%$ adduct concentration, $\mathrm{NaOH}$ digested bastnäsite recoveries were $93 \%$ for $\mathrm{La}, 100 \%$ for $\mathrm{Ce}, 99 \%$ for $\mathrm{Pr}$, and $101 \%$ for $\mathrm{Nd}$ after 90 minutes. This is similar to the recoveries obtained through conventional atmospheric leaching with concentrated acid (93-102\%) (see Table 2).
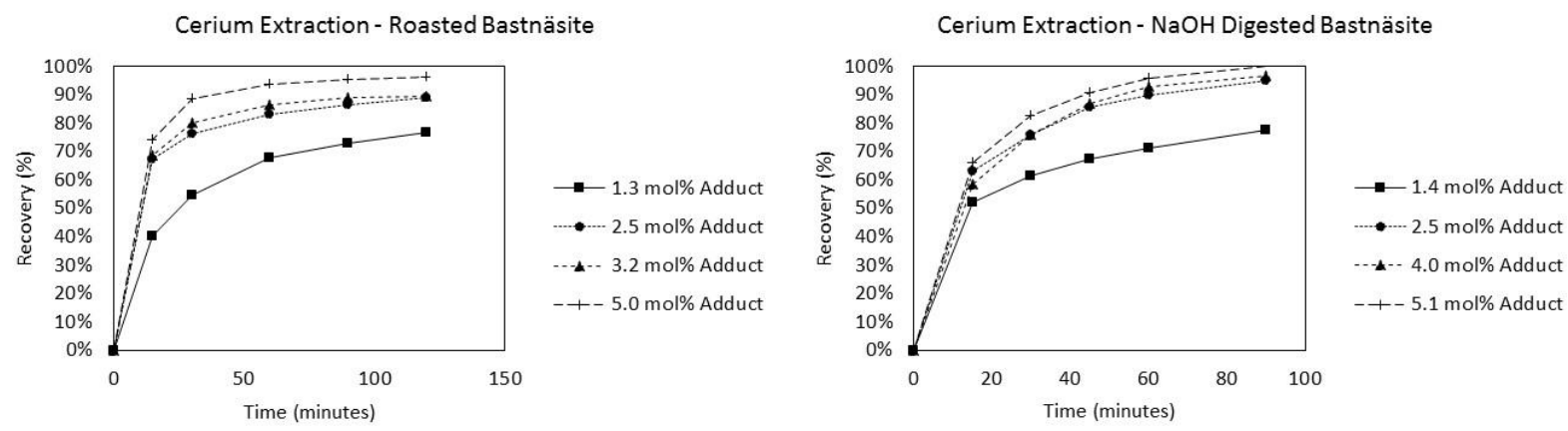

Figure 8 - Cerium recovery curves for various adduct concentrations for roasted bastnäsite (left) and $\mathrm{NaOH}$ digested bastnäsite (right). Conditions: $34 \mathrm{MPa}, 65^{\circ} \mathrm{C}, 4 \mathrm{~mol} / \mathrm{L} \mathrm{H}^{+}$adduct composition

\subsection{Selectivity}

As shown in Table 4, barium and strontium analyses were below the reporting limit and recoveries could not be determined for almost all tests, whereas quantified calcium recovery ranged from $29 \%$ to $110 \%$. Greater than $100 \%$ recoveries for calcium were attributed to contamination resulting from incomplete washing or rinsing of glassware. It can therefore be concluded that although precise recoveries were not always measureable for the three primary gangue elements, selectivity for lanthanides was superior to concentrated acid leaching (see Table 2).

Table 4 - Supercritical extraction results. All runs were performed at $65^{\circ} \mathrm{C}$ and $34 \mathrm{MPa}$.

\begin{tabular}{|c|c|c|c|c|c|c|c|c|c|c|c|}
\hline Run & Material & $\begin{array}{l}\text { Adduct } \\
\text { mol } \% \\
\text { in } \mathrm{CO}_{2} \\
\end{array}$ & $\begin{array}{c}\text { Adduct } \\
\text { Compositio } \\
\mathrm{n}\end{array}$ & $\begin{array}{c}\text { Time } \\
\text { (minutes) }\end{array}$ & \multicolumn{7}{|c|}{ Recovery (\%) } \\
\hline & & & & & $\mathrm{La}$ & $\mathrm{Ce}$ & $\operatorname{Pr}$ & $\mathrm{Nd}$ & $\mathrm{Ba}$ & $\mathrm{Ca}$ & $\mathrm{Sr}$ \\
\hline 1 & $\begin{array}{l}\text { Untreated } \\
\text { Bastnäsite }\end{array}$ & $5.2 \%$ & $\begin{array}{l}4 \mathrm{~mol} / \mathrm{L} \mathrm{H}^{+} \\
\text {Adduct }\end{array}$ & 15 & $1 \%$ & $1 \%$ & $3 \%$ & $3 \%$ & $<1 \%$ & $<1 \%$ & $<1 \%$ \\
\hline
\end{tabular}




\begin{tabular}{|c|c|c|c|c|c|c|c|c|c|c|c|}
\hline \multirow[t]{2}{*}{ Run } & \multirow[t]{2}{*}{ Material } & \multirow[t]{2}{*}{$\begin{array}{c}\text { Adduct } \\
\text { mol\% } \\
\text { in } \mathrm{CO}_{2}\end{array}$} & \multirow[t]{2}{*}{$\begin{array}{c}\text { Adduct } \\
\text { Compositio } \\
\mathrm{n} \\
\end{array}$} & \multirow[t]{2}{*}{$\begin{array}{c}\text { Time } \\
\text { (minutes) }\end{array}$} & \multicolumn{7}{|c|}{ Recovery (\%) } \\
\hline & & & & & $\mathrm{La}$ & $\mathrm{Ce}$ & $\operatorname{Pr}$ & $\mathrm{Nd}$ & $\mathrm{Ba}$ & $\mathrm{Ca}$ & $\mathrm{Sr}$ \\
\hline & & & & 30 & $3 \%$ & $2 \%$ & $5 \%$ & $6 \%$ & $<1 \%$ & $<2 \%$ & $<1 \%$ \\
\hline & & & & 45 & $4 \%$ & $3 \%$ & $6 \%$ & $8 \%$ & $<1 \%$ & $<2 \%$ & $<1 \%$ \\
\hline & & & & 60 & $5 \%$ & $4 \%$ & $8 \%$ & $9 \%$ & $<1 \%$ & $<3 \%$ & $<1 \%$ \\
\hline \multirow[t]{4}{*}{2} & \multirow[t]{4}{*}{$\begin{array}{l}\text { Roasted } \\
\text { Bastnäsite }\end{array}$} & \multirow[t]{4}{*}{$4.4 \%$} & \multirow[t]{4}{*}{$\begin{array}{l}6 \mathrm{~mol} / \mathrm{L} \mathrm{H}^{+} \\
\text {Adduct }\end{array}$} & 15 & $15 \%$ & $35 \%$ & $26 \%$ & $31 \%$ & $<3 \%$ & $19 \%$ & $<5 \%$ \\
\hline & & & & 30 & $28 \%$ & $49 \%$ & $44 \%$ & $50 \%$ & $<4 \%$ & $28 \%$ & $<7 \%$ \\
\hline & & & & 45 & $36 \%$ & $56 \%$ & $53 \%$ & $61 \%$ & $<5 \%$ & $38 \%$ & $<9 \%$ \\
\hline & & & & 60 & $41 \%$ & $61 \%$ & $58 \%$ & $68 \%$ & $<6 \%$ & $47 \%$ & $<10 \%$ \\
\hline \multirow[t]{4}{*}{3} & \multirow[t]{4}{*}{$\begin{array}{l}\text { Roasted } \\
\text { Bastnäsite }\end{array}$} & \multirow[t]{4}{*}{$4.5 \%$} & \multirow[t]{4}{*}{$\begin{array}{l}5 \mathrm{~mol} / \mathrm{L} \mathrm{H}^{+} \\
\text {Adduct }\end{array}$} & 15 & $16 \%$ & $69 \%$ & $41 \%$ & $40 \%$ & $<2 \%$ & $8 \%$ & $<2 \%$ \\
\hline & & & & 30 & $29 \%$ & $84 \%$ & $63 \%$ & $61 \%$ & $<3 \%$ & $12 \%$ & $<3 \%$ \\
\hline & & & & 45 & $45 \%$ & $90 \%$ & $75 \%$ & $70 \%$ & $<4 \%$ & $19 \%$ & $<4 \%$ \\
\hline & & & & 60 & $56 \%$ & $93 \%$ & $81 \%$ & $75 \%$ & $<5 \%$ & $29 \%$ & $<5 \%$ \\
\hline \multirow[t]{4}{*}{4} & \multirow[t]{4}{*}{$\begin{array}{l}\text { Roasted } \\
\text { Bastnäsite }\end{array}$} & \multirow[t]{4}{*}{$5.2 \%$} & \multirow[t]{4}{*}{$\begin{array}{l}4 \mathrm{~mol} / \mathrm{L} \mathrm{H}^{+} \\
\text {Adduct }\end{array}$} & 15 & $24 \%$ & $75 \%$ & $51 \%$ & $58 \%$ & $<2 \%$ & $8 \%$ & $<4 \%$ \\
\hline & & & & 30 & $39 \%$ & $86 \%$ & $70 \%$ & $77 \%$ & $<4 \%$ & $17 \%$ & $<8 \%$ \\
\hline & & & & 45 & $51 \%$ & $91 \%$ & $79 \%$ & $84 \%$ & $<6 \%$ & $26 \%$ & $<12 \%$ \\
\hline & & & & 60 & $62 \%$ & $94 \%$ & $84 \%$ & $88 \%$ & $<8 \%$ & $39 \%$ & $<15 \%$ \\
\hline \multirow[t]{4}{*}{5} & \multirow[t]{4}{*}{$\begin{array}{l}\text { Roasted } \\
\text { Bastnäsite }\end{array}$} & \multirow[t]{4}{*}{$5.2 \%$} & \multirow[t]{4}{*}{$\begin{array}{l}3 \mathrm{~mol} / \mathrm{L} \mathrm{H}^{+} \\
\text {Adduct }\end{array}$} & 15 & $33 \%$ & $82 \%$ & $68 \%$ & $66 \%$ & $<1 \%$ & $16 \%$ & $<2 \%$ \\
\hline & & & & 30 & $46 \%$ & $89 \%$ & $81 \%$ & $76 \%$ & $<2 \%$ & $25 \%$ & $<2 \%$ \\
\hline & & & & 45 & $57 \%$ & $92 \%$ & $87 \%$ & $80 \%$ & $<3 \%$ & $34 \%$ & $<3 \%$ \\
\hline & & & & 60 & $67 \%$ & $94 \%$ & $90 \%$ & $82 \%$ & $<3 \%$ & $47 \%$ & $<3 \%$ \\
\hline \multirow[t]{4}{*}{6} & \multirow[t]{4}{*}{$\begin{array}{l}\text { Roasted } \\
\text { Bastnäsite }\end{array}$} & \multirow[t]{4}{*}{$6.0 \%$} & $\begin{array}{l}2 \mathrm{~mol} / \mathrm{L} \mathrm{H}^{+} \\
\text {Adduct }\end{array}$ & 15 & $30 \%$ & $17 \%$ & $19 \%$ & $16 \%$ & $<1 \%$ & $38 \%$ & $2 \%$ \\
\hline & & & & 30 & $49 \%$ & $40 \%$ & $39 \%$ & $34 \%$ & $<1 \%$ & $45 \%$ & $4 \%$ \\
\hline & & & & 45 & $59 \%$ & $51 \%$ & $50 \%$ & $43 \%$ & $<2 \%$ & $50 \%$ & $5 \%$ \\
\hline & & & & 60 & $66 \%$ & $58 \%$ & $57 \%$ & $49 \%$ & $<3 \%$ & $54 \%$ & $5 \%$ \\
\hline 7 & $\begin{array}{l}\text { Roasted } \\
\text { Bastnäsite }\end{array}$ & $5.0 \%$ & $\begin{array}{l}4 \mathrm{~mol} / \mathrm{L} \mathrm{H}^{+} \\
\text {Adduct }\end{array}$ & 15 & $21 \%$ & $74 \%$ & $48 \%$ & $54 \%$ & $<2 \%$ & $5 \%$ & $<4 \%$ \\
\hline & & & & 30 & $39 \%$ & $89 \%$ & $70 \%$ & $75 \%$ & $<4 \%$ & $11 \%$ & $<8 \%$ \\
\hline & & & & 60 & $58 \%$ & $94 \%$ & $82 \%$ & $86 \%$ & $<7 \%$ & $25 \%$ & $<14 \%$ \\
\hline & & & & 90 & $67 \%$ & $96 \%$ & $86 \%$ & $89 \%$ & $<11 \%$ & $38 \%$ & $<22 \%$ \\
\hline & & & & 120 & $72 \%$ & $96 \%$ & $88 \%$ & $90 \%$ & $<15 \%$ & $50 \%$ & $<29 \%$ \\
\hline 8 & $\begin{array}{l}\text { Roasted } \\
\text { Bastnäsite }\end{array}$ & $3.2 \%$ & $\begin{array}{l}4 \mathrm{~mol} / \mathrm{L} \mathrm{H}^{+} \\
\text {Adduct }\end{array}$ & 15 & $10 \%$ & $69 \%$ & $36 \%$ & $40 \%$ & $<1 \%$ & $<15 \%$ & $<1 \%$ \\
\hline & & & & 30 & $18 \%$ & $80 \%$ & $53 \%$ & $60 \%$ & $<1 \%$ & $<30 \%$ & $<1 \%$ \\
\hline & & & & 60 & $33 \%$ & $87 \%$ & $69 \%$ & $75 \%$ & $<2 \%$ & $<55 \%$ & $<2 \%$ \\
\hline & & & & 90 & $47 \%$ & $89 \%$ & $77 \%$ & $81 \%$ & $<3 \%$ & $<80 \%$ & $<3 \%$ \\
\hline & & & & 120 & $52 \%$ & $90 \%$ & $79 \%$ & $82 \%$ & $<4 \%$ & $\begin{array}{c}<107 \\
\% \\
\end{array}$ & $<4 \%$ \\
\hline 9 & $\begin{array}{l}\text { Roasted } \\
\text { Bastnäsite }\end{array}$ & $2.5 \%$ & $\begin{array}{l}4 \mathrm{~mol} / \mathrm{L} \mathrm{H}^{+} \\
\text {Adduct }\end{array}$ & 15 & $7 \%$ & $67 \%$ & $24 \%$ & $27 \%$ & $<1 \%$ & $<16 \%$ & $<1 \%$ \\
\hline & & & & 30 & $12 \%$ & $77 \%$ & $36 \%$ & $42 \%$ & $<1 \%$ & $<31 \%$ & $<1 \%$ \\
\hline
\end{tabular}




\begin{tabular}{|c|c|c|c|c|c|c|c|c|c|c|c|}
\hline Run & Material & $\begin{array}{l}\text { Adduct } \\
\text { mol\% } \\
\text { in } \mathrm{CO}_{2}\end{array}$ & $\begin{array}{c}\text { Adduct } \\
\text { Compositio } \\
\mathrm{n}\end{array}$ & $\begin{array}{c}\text { Time } \\
\text { (minutes) }\end{array}$ & \multicolumn{7}{|c|}{ Recovery (\%) } \\
\hline & & & & & $\mathrm{La}$ & $\mathrm{Ce}$ & $\operatorname{Pr}$ & $\mathrm{Nd}$ & $\mathrm{Ba}$ & $\mathrm{Ca}$ & $\mathrm{Sr}$ \\
\hline & & & & 60 & $21 \%$ & $83 \%$ & $53 \%$ & $61 \%$ & $<2 \%$ & $<52 \%$ & $<2 \%$ \\
\hline & & & & 90 & $28 \%$ & $87 \%$ & $61 \%$ & $67 \%$ & $<3 \%$ & $<73 \%$ & $<3 \%$ \\
\hline & & & & 120 & $35 \%$ & $89 \%$ & $67 \%$ & $72 \%$ & $<3 \%$ & $<95 \%$ & $<3 \%$ \\
\hline \multirow[t]{5}{*}{10} & \multirow[t]{5}{*}{$\begin{array}{l}\text { Roasted } \\
\text { Bastnäsite }\end{array}$} & \multirow[t]{5}{*}{$1.3 \%$} & \multirow[t]{5}{*}{$\begin{array}{l}4 \mathrm{~mol} / \mathrm{L} \mathrm{H}^{+} \\
\text {Adduct }\end{array}$} & 15 & $4 \%$ & $40 \%$ & $26 \%$ & $34 \%$ & $<1 \%$ & $<15 \%$ & $<1 \%$ \\
\hline & & & & 30 & $6 \%$ & $55 \%$ & $35 \%$ & $44 \%$ & $<1 \%$ & $<30 \%$ & $<1 \%$ \\
\hline & & & & 60 & $11 \%$ & $68 \%$ & $48 \%$ & $59 \%$ & $<2 \%$ & $<51 \%$ & $<2 \%$ \\
\hline & & & & 90 & $17 \%$ & $73 \%$ & $58 \%$ & $68 \%$ & $<3 \%$ & $<72 \%$ & $<3 \%$ \\
\hline & & & & 120 & $26 \%$ & $77 \%$ & $68 \%$ & $77 \%$ & $<3 \%$ & $<94 \%$ & $<3 \%$ \\
\hline \multirow[t]{4}{*}{11} & \multirow[t]{4}{*}{$\begin{array}{l}\mathrm{NaOH} \\
\text { Digested } \\
\text { Bastnäsite }\end{array}$} & \multirow[t]{4}{*}{$4.6 \%$} & \multirow[t]{4}{*}{$\begin{array}{l}6 \mathrm{~mol} / \mathrm{L} \mathrm{H}^{+} \\
\text {Adduct }\end{array}$} & 15 & $37 \%$ & $33 \%$ & $57 \%$ & $60 \%$ & $<2 \%$ & $12 \%$ & $<5 \%$ \\
\hline & & & & 30 & $60 \%$ & $46 \%$ & $75 \%$ & $78 \%$ & $<3 \%$ & $33 \%$ & $<6 \%$ \\
\hline & & & & 45 & $76 \%$ & $58 \%$ & $87 \%$ & $90 \%$ & $<5 \%$ & $57 \%$ & $<9 \%$ \\
\hline & & & & 60 & $83 \%$ & $62 \%$ & $92 \%$ & $95 \%$ & $<6 \%$ & $80 \%$ & $<11 \%$ \\
\hline \multirow[t]{4}{*}{12} & \multirow[t]{4}{*}{$\begin{array}{l}\mathrm{NaOH} \\
\text { Digested } \\
\text { Bastnäsite }\end{array}$} & \multirow[t]{4}{*}{$4.6 \%$} & \multirow[t]{4}{*}{$\begin{array}{l}5 \mathrm{~mol} / \mathrm{L} \mathrm{H}{ }^{+} \\
\text {Adduct }\end{array}$} & 15 & $24 \%$ & $75 \%$ & $64 \%$ & $65 \%$ & $<2 \%$ & $19 \%$ & $<2 \%$ \\
\hline & & & & 30 & $45 \%$ & $86 \%$ & $88 \%$ & $83 \%$ & $<3 \%$ & $23 \%$ & $<3 \%$ \\
\hline & & & & 45 & $71 \%$ & $92 \%$ & $98 \%$ & $89 \%$ & $<4 \%$ & $35 \%$ & $<4 \%$ \\
\hline & & & & 60 & $83 \%$ & $93 \%$ & $100 \%$ & $90 \%$ & $<5 \%$ & $44 \%$ & $<5 \%$ \\
\hline \multirow[t]{4}{*}{13} & \multirow[t]{4}{*}{$\begin{array}{l}\mathrm{NaOH} \\
\text { Digested } \\
\text { Bastnäsite }\end{array}$} & \multirow[t]{4}{*}{$4.9 \%$} & \multirow[t]{4}{*}{$\begin{array}{l}4 \mathrm{~mol} / \mathrm{L} \mathrm{H}^{+} \\
\text {Adduct }\end{array}$} & 15 & $36 \%$ & $59 \%$ & $62 \%$ & $68 \%$ & $<1 \%$ & $<21 \%$ & $<1 \%$ \\
\hline & & & & 30 & $62 \%$ & $77 \%$ & $85 \%$ & $89 \%$ & $<1 \%$ & $<40 \%$ & $<1 \%$ \\
\hline & & & & 45 & $81 \%$ & $82 \%$ & $95 \%$ & $96 \%$ & $<2 \%$ & $<58 \%$ & $<2 \%$ \\
\hline & & & & 60 & $94 \%$ & $85 \%$ & $99 \%$ & $98 \%$ & $<3 \%$ & $<77 \%$ & $<3 \%$ \\
\hline \multirow[t]{4}{*}{14} & \multirow[t]{4}{*}{$\begin{array}{l}\mathrm{NaOH} \\
\text { Digested } \\
\text { Bastnäsite }\end{array}$} & \multirow[t]{4}{*}{$4.6 \%$} & \multirow[t]{4}{*}{$\begin{array}{l}3 \mathrm{~mol} / \mathrm{L} \mathrm{H}^{+} \\
\text {Adduct }\end{array}$} & 15 & $44 \%$ & $62 \%$ & $69 \%$ & $64 \%$ & $<1 \%$ & $8 \%$ & $<1 \%$ \\
\hline & & & & 30 & $61 \%$ & $77 \%$ & $85 \%$ & $78 \%$ & $<2 \%$ & $13 \%$ & $<2 \%$ \\
\hline & & & & 45 & $83 \%$ & $87 \%$ & $94 \%$ & $84 \%$ & $<3 \%$ & $30 \%$ & $<3 \%$ \\
\hline & & & & 60 & $87 \%$ & $89 \%$ & $96 \%$ & $85 \%$ & $<3 \%$ & $33 \%$ & $<3 \%$ \\
\hline \multirow[t]{4}{*}{15} & \multirow[t]{4}{*}{$\begin{array}{l}\mathrm{NaOH} \\
\text { Digested } \\
\text { Bastnäsite }\end{array}$} & \multirow[t]{4}{*}{$5.1 \%$} & \multirow[t]{4}{*}{$\begin{array}{l}2 \mathrm{~mol} / \mathrm{L} \mathrm{H}^{+} \\
\text {Adduct }\end{array}$} & 15 & $86 \%$ & $50 \%$ & $88 \%$ & $75 \%$ & $<1 \%$ & $>86 \%$ & $8 \%$ \\
\hline & & & & 30 & $93 \%$ & $56 \%$ & $95 \%$ & $81 \%$ & $<1 \%$ & $105 \%$ & $14 \%$ \\
\hline & & & & 45 & $94 \%$ & $58 \%$ & $96 \%$ & $82 \%$ & $<2 \%$ & $109 \%$ & $18 \%$ \\
\hline & & & & 60 & $94 \%$ & $59 \%$ & $96 \%$ & $82 \%$ & $<3 \%$ & $110 \%$ & $20 \%$ \\
\hline \multirow[t]{4}{*}{16} & $\begin{array}{l}\mathrm{NaOH} \\
\text { Digested } \\
\text { Bastnäsite }\end{array}$ & $5.1 \%$ & $\begin{array}{l}4 \mathrm{~mol} / \mathrm{L} \mathrm{H}^{+} \\
\text {Adduct }\end{array}$ & 15 & $29 \%$ & $66 \%$ & $59 \%$ & $67 \%$ & $<2 \%$ & $7 \%$ & $<4 \%$ \\
\hline & & & & 30 & $53 \%$ & $83 \%$ & $82 \%$ & $87 \%$ & $<4 \%$ & $14 \%$ & $<8 \%$ \\
\hline & & & & 45 & $67 \%$ & $91 \%$ & $90 \%$ & $94 \%$ & $<6 \%$ & $22 \%$ & $<12 \%$ \\
\hline & & & & 60 & $78 \%$ & $96 \%$ & $95 \%$ & $99 \%$ & $<8 \%$ & $29 \%$ & $<16 \%$ \\
\hline
\end{tabular}




\begin{tabular}{|c|c|c|c|c|c|c|c|c|c|c|c|}
\hline Run & Material & $\begin{array}{c}\text { Adduct } \\
\text { mol\% } \\
\text { in } \mathrm{CO}_{2}\end{array}$ & $\begin{array}{c}\text { Adduct } \\
\text { Compositio } \\
\mathrm{n}\end{array}$ & $\begin{array}{c}\text { Time } \\
\text { (minutes) }\end{array}$ & \multicolumn{7}{|c|}{ Recovery (\%) } \\
\hline & & & & & $\mathrm{La}$ & $\mathrm{Ce}$ & $\operatorname{Pr}$ & $\mathrm{Nd}$ & $\mathrm{Ba}$ & $\mathrm{Ca}$ & $\mathrm{Sr}$ \\
\hline & & & & 90 & $93 \%$ & $100 \%$ & $99 \%$ & $101 \%$ & $<12 \%$ & $46 \%$ & $<24 \%$ \\
\hline \multirow[t]{5}{*}{17} & \multirow[t]{5}{*}{$\begin{array}{l}\mathrm{NaOH} \\
\text { Digested } \\
\text { Bastnäsite }\end{array}$} & \multirow[t]{5}{*}{$3.9 \%$} & \multirow[t]{5}{*}{$\begin{array}{l}4 \mathrm{~mol} / \mathrm{L} \mathrm{H}^{+} \\
\text {Adduct }\end{array}$} & 15 & $22 \%$ & $58 \%$ & $49 \%$ & $55 \%$ & $<1 \%$ & $<16 \%$ & $<1 \%$ \\
\hline & & & & 30 & $44 \%$ & $76 \%$ & $72 \%$ & $76 \%$ & $<1 \%$ & $<31 \%$ & $<1 \%$ \\
\hline & & & & 45 & $60 \%$ & $87 \%$ & $84 \%$ & $86 \%$ & $<2 \%$ & $<47 \%$ & $<2 \%$ \\
\hline & & & & 60 & $76 \%$ & $93 \%$ & $91 \%$ & $92 \%$ & $<2 \%$ & $<63 \%$ & $<2 \%$ \\
\hline & & & & 90 & $91 \%$ & $97 \%$ & $97 \%$ & $96 \%$ & $<3 \%$ & $<91 \%$ & $<3 \%$ \\
\hline \multirow[t]{5}{*}{18} & \multirow[t]{5}{*}{$\begin{array}{l}\mathrm{NaOH} \\
\text { Digested } \\
\text { Bastnäsite }\end{array}$} & \multirow[t]{5}{*}{$2.5 \%$} & \multirow[t]{5}{*}{$\begin{array}{l}4 \mathrm{~mol} / \mathrm{L} \mathrm{H}^{+} \\
\text {Adduct }\end{array}$} & 15 & $11 \%$ & $63 \%$ & $41 \%$ & $46 \%$ & $<1 \%$ & $<16 \%$ & $<1 \%$ \\
\hline & & & & 30 & $22 \%$ & $76 \%$ & $57 \%$ & $64 \%$ & $<1 \%$ & $<32 \%$ & $<1 \%$ \\
\hline & & & & 45 & $42 \%$ & $86 \%$ & $75 \%$ & $80 \%$ & $<2 \%$ & $<52 \%$ & $<2 \%$ \\
\hline & & & & 60 & $53 \%$ & $90 \%$ & $83 \%$ & $87 \%$ & $<2 \%$ & $<68 \%$ & $<2 \%$ \\
\hline & & & & 90 & $74 \%$ & $95 \%$ & $95 \%$ & $95 \%$ & $<3 \%$ & $<90 \%$ & $<3 \%$ \\
\hline \multirow[t]{5}{*}{19} & \multirow[t]{5}{*}{$\begin{array}{l}\mathrm{NaOH} \\
\text { Digested } \\
\text { Bastnäsite }\end{array}$} & \multirow[t]{5}{*}{$1.4 \%$} & \multirow[t]{5}{*}{$\begin{array}{l}4 \mathrm{~mol} / \mathrm{L} \mathrm{H}^{+} \\
\text {Adduct }\end{array}$} & 15 & $7 \%$ & $52 \%$ & $34 \%$ & $38 \%$ & $<1 \%$ & $<16 \%$ & $<1 \%$ \\
\hline & & & & 30 & $12 \%$ & $61 \%$ & $42 \%$ & $48 \%$ & $<1 \%$ & $<32 \%$ & $<1 \%$ \\
\hline & & & & 45 & $17 \%$ & $67 \%$ & $50 \%$ & $56 \%$ & $<2 \%$ & $<47 \%$ & $<2 \%$ \\
\hline & & & & 60 & $21 \%$ & $71 \%$ & $56 \%$ & $61 \%$ & $<2 \%$ & $<63 \%$ & $<2 \%$ \\
\hline & & & & 90 & $27 \%$ & $78 \%$ & $64 \%$ & $69 \%$ & $<3 \%$ & $<85 \%$ & $<3 \%$ \\
\hline
\end{tabular}

\section{DISCUSSION}

\subsection{General Observations}

Several conclusions can be drawn from the extraction data. As expected, higher extraction rates are seen for heavier REEs due to their smaller atomic radius; the same trend has been seen previously in supercritical extraction of lanthanides [30]. For example, with $4 \mathrm{M} \mathrm{H}^{+}$adduct at $5 \mathrm{~mol} \%$ in $\mathrm{CO}_{2}, \mathrm{Nd}$ extraction rates were $30-100 \%$ faster than La extraction rates. It is also evident that reaction rates are similar for the two pretreatment methods, although they are slightly faster for the $\mathrm{NaOH}$ digested material. Assessment of the capital and operating costs associated with the two pretreatment methods, as well as the environmental impacts, should be used to fully evaluate the overall performance of the two pretreatment options.

\subsection{Kinetics}

Due to the number of steps involved in extraction (mass transfer to/from particle surface, formation of REE nitrate, coordination of the REE nitrate with TBP, and separation of the metal-containing complex from the particle surface), several assumptions were made in order to interpret the kinetic results:

- Temperature and pressure are constant within the reaction column;

- Reaction rates are not limited by fluid-phase mass transfer; this is justified based on the high porosity of the reaction column (estimated at 92 volume \%), the high diffusivity of the supercritical phase, and the small reaction column inner diameter $(5 \mathrm{~mm})$;

- Reaction rates are not limited by solid-phase diffusion; 
- Adduct concentrations were constant in the reaction column; given that the adduct was present in stoichiometric excess by a factor of 40-600 depending on the run, depletion of the adduct as it moved through the reaction column can safely be neglected.

Based on these assumptions, the reaction rates are limited by phenomena at the particle surface (nitration, complexation with TBP, and/or desorption of the complex). A shrinking particle model is appropriate, therefore, since this model is based on the principle that reaction rate is proportional to particle surface area [31]:

$$
1-(1-X)^{1 / 3}=k t
$$

Where $\mathrm{X}$ is the fraction reacted, $\mathrm{t}$ is time (s), and $\mathrm{k}$ is a reaction rate constant $\left(\mathrm{s}^{-1}\right)$. A reaction rate constant "k" was fitted to each recovery curve using a simple iterative solver to minimize residual square error. Because there were 19 tests with 4 REE extraction curves each, this resulted in $76 \mathrm{k}$ values. Each $\mathrm{k}$ value effectively encompasses the rate of reaction in a single number, allowing for the reaction rate to be plotted against relevant variables. These $\mathrm{k}$ values were plotted against TBP and $\mathrm{HNO}_{3}$ concentrations in the $\mathrm{CO}_{2}$ phase (which depends on the adduct composition and the mole $\%$ adduct in $\mathrm{CO}_{2}$ ).

In the case of lanthanum, the reaction rate constant appears to show a linear dependence on the TBP concentration in the $\mathrm{CO}_{2}$ phase, regardless of the $\mathrm{HNO}_{3}$ concentration present (see Figure 9). This suggests that complexation of the lanthanum nitrate with TBP is the rate-limiting step. A slow rate of lanthanum-TBP complexation is logical as lanthanum has the least affinity for TBP due to its large atomic radius. It appears that the trend becomes nonlinear at low concentrations.

For cerium, there is an increase in reaction rate with $\mathrm{HNO}_{3}$ concentration up to about $1.5 \mathrm{~mol} / \mathrm{L} \mathrm{HNO}_{3}$ in the $\mathrm{CO}_{2}$ phase (corresponding to the $4 \mathrm{M} \mathrm{H}^{+}$adduct at approximately $5 \mathrm{~mol} \%$ in $\mathrm{CO}_{2}$ ). At this point recovery rates decrease again (see Figure 9). This suggests that nitration is the rate-limiting step, but high acid concentrations inhibit extraction. A similar trend is evident for praseodymium and neodymium (not shown).

A previous study of the supercritical extraction of neodymium oxide with $\mathrm{TBP} / \mathrm{HNO}_{3}$ adducts also found that reaction rates peaked with adducts containing 3-4 mol/ $\mathrm{L} \mathrm{H}^{+}$. It was suggested that high $\mathrm{HNO}_{3}$ concentrations resulted in the formation of an aqueous phase which sequestered the REEs [14]. This can be exacerbated by the water generated during the reaction between REE minerals and the adduct (see Reactions 7 and 8). A second possible explanation for the drop in recovery rate at high acid concentration is competition between $\mathrm{HNO}_{3}$ and the lanthanide nitrates for complexation with TBP. Such a phenomenon has been seen in conventional $\mathrm{TBP} / \mathrm{HNO}_{3}$ solvent extraction; extraction of lanthanides increases with aqueous phase acidity up to $3-5 \mathrm{~mol} / \mathrm{L} \mathrm{H}^{+}$, then recovery begins decreasing again as nitric acid competes with lanthanide nitrates for TBP complexation $[4,32]$.
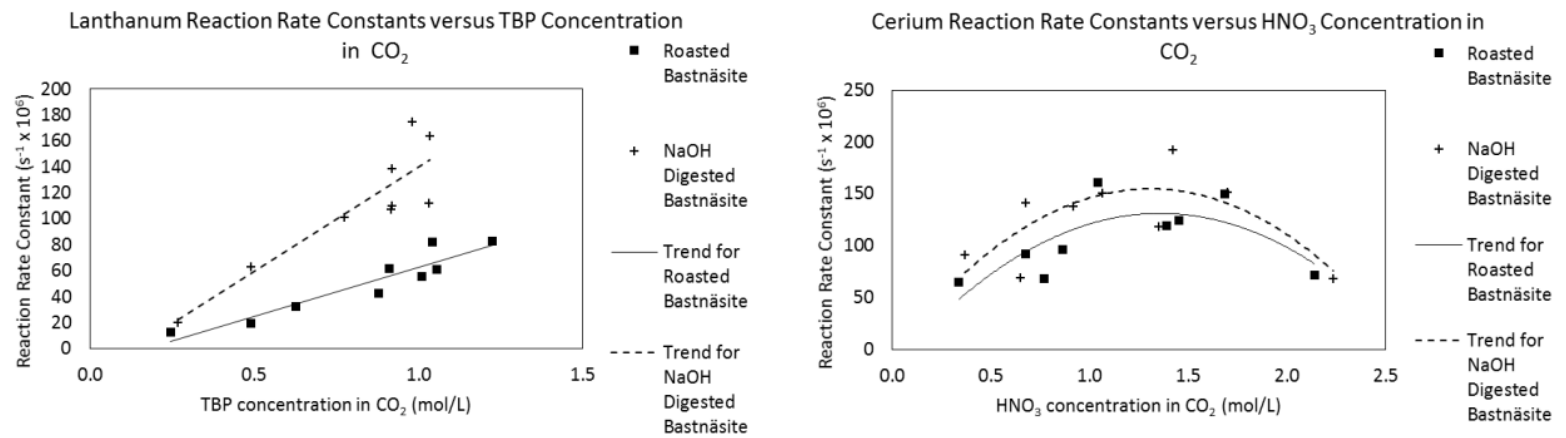

Figure 9 - Lanthanum reaction rate constant versus TBP concentration in $\mathrm{CO}_{2}$ phase (left) and cerium reaction constant rate constant versus $\mathrm{HNO}_{3}$ concentration in $\mathrm{CO}_{2}$ phase (right)

\section{CONCLUSIONS}

This study has demonstrated that rare earth elements can be extracted from bastnäsite concentrate using standard pretreatment methods followed by supercritical carbon dioxide extraction with tributyl phosphate/nitric acid adducts. $\mathrm{La}, \mathrm{Ce}, \mathrm{Pr}$, and $\mathrm{Nd}$ recoveries were similar to conventional leaching with concentrated nitric acid. Though both roasted and $\mathrm{NaOH}$ digested bastnäsite achieved similar recoveries, extraction was marginally faster for the $\mathrm{NaOH}$ digested sample, particularly for lanthanum extraction. Selectivity for REEs over gangue elements was superior to concentrated nitric acid leaching: with $4 \mathrm{M} \mathrm{H}^{+}$adduct at $5 \mathrm{~mol} \%$ in $\mathrm{CO}_{2}$, calcium recoveries were 
approximately half of those observed in concentrated nitric acid leaching, and barium and strontium were generally below the reporting limit.

In general, higher atomic numbers resulted in more rapid extraction, corresponding to the greater affinity to TBP. For example, with $4 \mathrm{M} \mathrm{H}^{+}$adduct at $5 \mathrm{~mol} \%$ in $\mathrm{CO}_{2}$, Nd extraction rates were $30-100 \%$ faster than $\mathrm{La}$ extraction rates. Various adduct compositions $\left(\mathrm{TBP} / \mathrm{HNO}_{3}\right.$ ratios) and adduct mole $\%$ in the $\mathrm{CO}_{2}$ phase were compared. By fitting the recovery curves to a surface-reaction limited model, the apparent first-order reaction rate constant for cerium, praseodymium, and neodymium increased with $\mathrm{HNO}_{3}$ concentration in the $\mathrm{CO}_{2}$ phase up to approximately $1.5 \mathrm{~mol} / \mathrm{L} \mathrm{HNO}_{3}$, at which point recovery decreased, likely due to droplet condensation or competition between lanthanide nitrates and nitric acid for TBP complexation. For lanthanum, the reaction rate simply increased with TBP concentration in the $\mathrm{CO}_{2}$ phase, possibly indicating that the lanthanum extraction rate is limited by TBP complexation.

This study is an important first step in demonstrating the application of SFE technology to REE primary sources. Further work is required to demonstrate downstream processing stages, particularly separation of individual REEs. This would require studying the precipitation of various elements from the supercritical phase via pressure drops of various magnitudes. Further work is also required to demonstrate how different concentrates would respond to SFE. If the number of extraction stages and/or the consumption of reagents can be reduced relative to conventional extraction routes, supercritical extraction could have the potential to reduce the costs and environmental impact of REE processing.

\section{ACKNOWLEDGMENTS}

Partial funding was provided by the Department of Energy Critical Materials Institute and the Cornell Energy Institute. A portion of this work was completed at the Idaho National Laboratory under Department of Energy Idaho Operations Office Contract DE-AC07-05ID14517. Sonic sifting data was obtained at the Cornell Nanoscale Science and Technology Facility (National Science Foundation grant number ECCS-1542081). The authors wish to thank Mary Case and Bruce Mincher at the Idaho National Laboratory, Chien Wai at the University of Idaho, and Maura Weathers, Lou Derry, Gregg McElwee, Ella Fu, and Arna Pálsdóttir at Cornell University. 


\section{REFERENCES}

[1] F. Xie, T.A. Zhang, D. Dreisinger, F. Doyle, A critical review on solvent extraction of rare earths from aqueous solutions, Miner. Eng. 56 (2014) 10-28. doi:10.1016/j.mineng.2013.10.021.

[2] United States Department of Energy, Critical materials strategy, 2011. http://energy.gov/sites/prod/files/DOE_CMS2011_FINAL_Full.pdf.

[3] N. Krishnamurthy, C.K. Gupta, Extractive Metallurgy of Rare Earths, CRC Press, 2004. https://books.google.com/books?id=F0Bte_XhzoAC.

[4] J. Zhang, B. Zhao, Separation Hydrometallurgy of Rare Earth Elements, Springer, 2016. doi:10.1007/978-3319-28235-0.

[5] E. Vahidi, H. Zhao, Life Cycle Analysis for Solvent Extraction of Rare Earth Elements from Aqueous Solutions, in: Rewas 2016 Towar. Mater. Resour. Sustain., The Minerals, Metals \& Materials Society, 2016. doi:1002/9781119275039.ch17.

[6] N. Haque, A. Hughes, S. Lim, C. Vernon, Rare Earth Elements: Overview of Mining, Mineralogy, Uses, Sustainability and Environmental Impact, Resources. 3 (2014) 614-635. doi:10.3390/resources3040614.

[7] Y. Lin, C.M. Wal, Supercritical fluid extraction of lanthanides with fluorinated $\beta$-diketones and tributyl phosphate, Anal. Chem. 66 (1994) 1971-1975. doi:10.1021/ac00085a008.

[8] K.E. Laintz, E. Tachikawa, Extraction of lanthanides from acidic solution using tributyl phosphate modified supercritical carbon dioxide, Anal. Chem. 66 (1994) 2190-2193. http://pubs.acs.org/doi/abs/10.1021/ac00085a040.

[9] F. Dehghani, T. Wells, N.J. Cotton, N.R. Foster, Extraction and Separation of Lanthanides Using Dense Gas CO2 Modified with Tributyl Phosphate and di (2-Ethylhexyl ) Phosphoric Acid, J. Supercrit. Fluids. 9 (1996) 263-272.

[10] Y. Lin, N.G. Smart, C.M. Wai, Supercritical fluid extraction of uranium and thorium from nitric acid solutions with organophosphorus reagents, Environ. Sci. Technol. 29 (1995) 2706-2708. doi:10.1021/es00010a036.

[11] R. V. Fox, R.D. Ball, P.D.B. Harrington, H.W. Rollins, J.J. Jolley, C.M. Wai, Praseodymium nitrate and neodymium nitrate complexation with organophosphorus reagents in supercritical carbon dioxide solvent, J. Supercrit. Fluids. 31 (2004) 273-286. doi:10.1016/j.supflu.2003.11.006.

[12] L.Y. Zhu, W.H. Duan, J.M. Xu, Y.J. Zhu, Conversion of neodymium oxide with N2O4 into nitrate followed by supercritical fluid extraction of nitrate.pdf, (2011) 443-448. doi:10.1007/s10967-010-0701-7.

[13] R. V. Fox, R.D. Ball, P.D.B. Harrington, H.W. Rollins, C.M. Wai, Holmium nitrate complexation with tri-nbutyl phosphate in supercritical carbon dioxide, J. Supercrit. Fluids. 36 (2005) 137-144. doi:10.1016/j.supflu.2005.05.003.

[14] D. Wuhua, C. Pijia, Z. Yongjun, Extraction of rare earth elements from their oxides using organophosphorus reagent complexes with HNO3 and $\mathrm{H} 2 \mathrm{O}$ in supercritical CO2, J. Rare Earths. 28 (2010) 221-226. doi:10.1016/S1002-0721(09)60084-3.

[15] L. Zhu, W. Duan, J. Xu, Y. Zhu, Kinetics of Reactive Extraction of Nd from Nd2O3 with TBP-HNO3 Complex in Supercritical Carbon Dioxide, Chinese J. Chem. Eng. 17 (2009) 214-218. doi:10.1016/S10049541(08)60196-2.

[16] D.L. Baek, R. V. Fox, M.E. Case, L.K. Sinclair, A.B. Schmidt, P.R. McIlwain, B.J. Mincher, C.M. Wai, Extraction of Rare Earth Oxides Using Supercritical Carbon Dioxide Modified with Tri- $n$-Butyl Phosphate-Nitric Acid Adducts, Ind. Eng. Chem. Res. 55 (2016) 7154-7163. doi:10.1021/acs.iecr.6b00554.

[17] O. Tomioka, Y. Enokida, I. Yamamoto, Selective recovery of neodymium from oxides by direct extraction method with supercritical CO2 containing TBP-HNO 3 complex, Sep. Sci. Technol. 37 (2002) 1153-1162. doi:10.1081/SS-120002247. 
[18] M.D. Samsonov, T.I. Trofimov, Y.M. Kulyako, S.E. Vinokurov, D.A. Malikov, G.S. Batorshin, B.F. Myasoedov, Recovery of rare earth elements, uranium, and thorium from monazite concentrate by supercritical fluid extraction, Radiochemistry. 57 (2015) 343-347. doi:10.1134/S1066362215040025.

[19] O. Tomioka, Y. Enokida, I. Yamamoto, Solvent Extraction of Lanthanides from their Oxides with TBP in Supercritical Carbon Dioxide, J. Nucl. Sci. Technol. 35 (1998) 515-516.

[20] M. Kul, Y. Topkaya, I. Karakaya, Rare earth double sulfates from pre-concentrated bastnasite, Hydrometallurgy. 93 (2008) 129-135. doi:10.1016/j.hydromet.2007.11.008.

[21] L.K. Sinclair, D.L. Baek, R. V. Fox, Pretreatment Methods for Rare Earth Element Extraction in Supercritical Carbon Dioxide, in: XXVIII Int. Miner. Process. Congr., Quebec City, Canada, 2016.

[22] The International Centre for Diffraction Data, PDF-2 Technical Bulletin, (2013).

[23] A. Yörükoğlu, A. Obut, I. Girgin, Effect of thiourea on sulphuric acid leaching of bastnaesite, Hydrometallurgy. 68 (2003) 195-202. doi:10.1016/S0304-386X(02)00199-8.

[24] J. Xiang, C. Zhang, G. Tu, C. Ren, Thermal Decomposition Behaviour of Natural Bastnasite Crystal in Calcination, Trans. Nonferrous Met. Soc. China. 4 (1994) 34-38.

[25] S. Suchen, W. Zhiying, G. Bo, B. Xue, W. Wenyuan, T. Ganfeng, Effect of $\mathrm{CaO}$ on Fluorine in the Decomposition of REFCO3, J. Rare Earths. 25 (2007) 508-511. doi:10.1016/S1002-0721(07)60465-7.

[26] ASTM E161-12, Standard Specification for Precision Electroformed Sieves, (2012). doi:10.1520/E0161-12.

[27] D.J. Bauer, V.E. Shaw, Metathesis of bastnasite and solvent extraction of cerium, Washington, D.C., 1964. https://hdl.handle.net/2027/mdp.39015077557083.

[28] Y. Enokida, O. Tomioka, S. Lee, A. Rustenholtz, C.M. Wai, Characterization of a Tri- n -butyl Phosphate Nitric Acid Complex : a CO2 -Soluble Extractant for Dissolution of Uranium Dioxide, Ind. Eng. Chem. Res. 42 (2003) 5037-5041.

[29] C.M. Wai, Y.-J. Liao, W. Liao, G. Tian, R.S. Addleman, D. Quach, S.P. Pasilis, Uranium dioxide in ionic liquid with a tri-n-butylphosphate-HNO3 complex--dissolution and coordination environment, Dalton Trans. 40 (2011) 5039-5045. doi:10.1039/c0dt01518k.

[30] R.V. Fox, Complexation reactions of lanthanides in supercritical fluid carbon dioxide, University of Idaho, 2003.

[31] J.M. Smith, Chemical engineering kinetics, McGraw-Hill, 1970. https://books.google.com/books?id=U8ZTAAAAMAAJ.

[32] D.E. Peppard, W.J. Driscoll, R.J. Sironen, S. McCarty, Nonmonotonic ordering of lanthanides in tributyl phosphate-nitric acid extraction systems, J. Inor. 4 (1957) 326-333. 

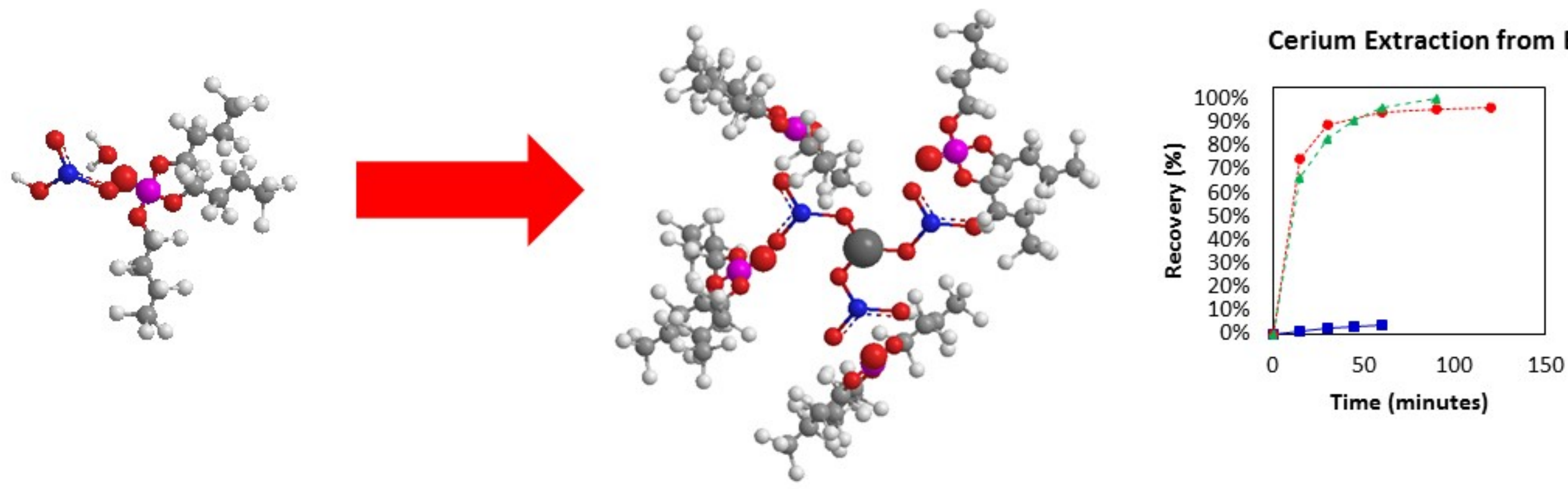

$\rightarrow$ - Untreated Bastnäsite

-.-. Roasted Bastnäsite

- - NaOH Digested Bastnäsite 